\title{
Tax 'societal ills' to save the planet
}

\section{Funding is a major stumbling block for environmental initiatives, says Edward Barbier. Taxing financial transactions or trade in arms, tobacco and fuel might help.}

$\mathrm{I}$ n June, the United Nations Conference on Sustainable Development, 'Rio+20', will aim to green the world economy and, at the same time, eradicate poverty. But progress at Rio +20 is likely to falter over a familiar stumbling block: financing.

Negotiations at conferences such as these are often focused on setting targets for action or making financial commitments, without negotiating the mechanisms by which those funds will be raised. This has resulted in large gaps between intended actions and actual funds, on the order of hundreds of billions of dollars.

Three revenue-raising mechanisms are often proposed: funds, global markets for carbon and ecosystem services, and revenues from global trade. The first two don't seem to hold much promise for generating the hundreds of billions of dollars needed. For example, the Green Climate Fund, agreed at the 2010 Cancun climate talks, promises up to US $\$ 100$ billion a year by 2020 to help developing countries to adjust to global warming; yet present international commitments to all climate funding total less than $\$ 2.5$ billion. Other funds face similar gaps.

The only global market for ecosystem services yet in operation is the nascent United Nations (UN) programme for reducing emissions from deforestation and forest degradation (REDD+). But the cost of reducing emissions in this way is far greater than the amount that nations could earn through carbon markets to finance the action ${ }^{1}$. UNREDD, a pilot initiative established by several UN agencies in 2008, has raised \$118 million - not nearly enough to make up the shortfall $^{2}$. As for carbon taxes and tradable emissions permits, politics, particularly in the United States, seems to have ruled out these options.

The third option - tapping global trade, including financial transactions - seems far more appealing (see 'Money makers'). There are several ways of doing this. An International Finance Facility (IFF) mobilizes resources from international capital markets by issuing long-term bonds that are repaid by donor countries over 20-30 years. An IFF for immunization, launched in 2006, has so far raised $\$ 3.6$ billion. Unlike other global financing mechanisms, an IFF can be started by just a few donor countries, and can be implemented through $\checkmark$ NATURE.COM Edward Barbier on the Global Green New Deal: go.nature.com/czjk5w

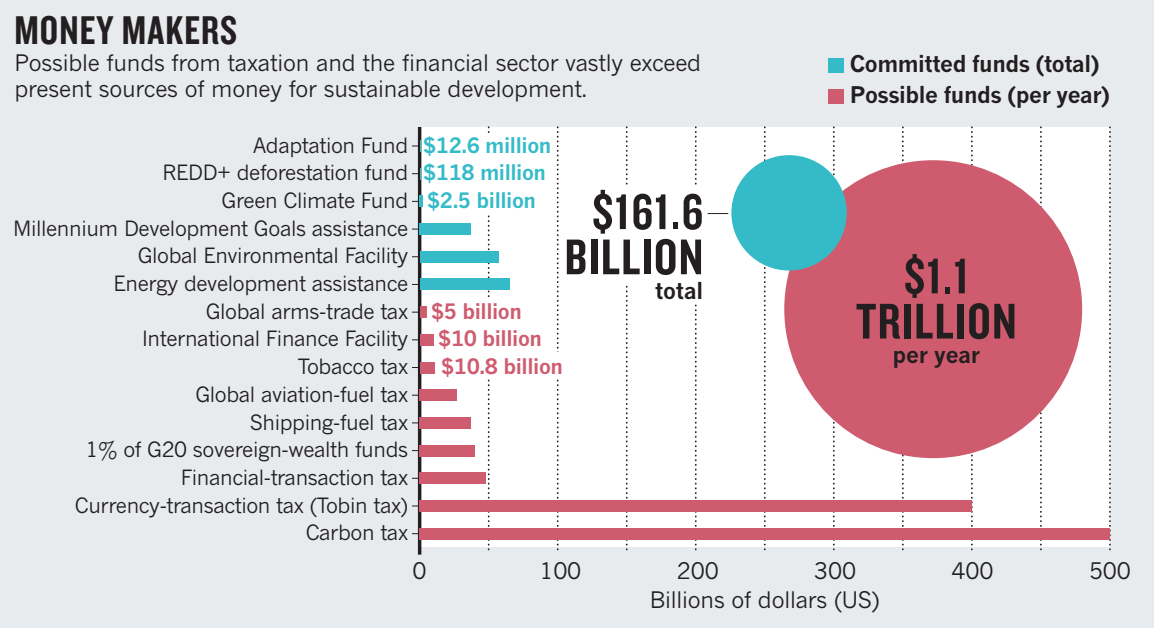

existing aid institutions, such as the World Bank. However, the amounts raised are likely to be in the tens, rather than hundreds, of billions of dollars.

Alternatively, the UN Conference on Trade and Development has proposed that developing economies invest $1 \%$ of their sovereign-wealth funds in regional development banks. Allocating just $1 \%$ from the sovereign-wealth funds of G20 countries would raise at least $\$ 40$ billion annually ${ }^{3}$.

\section{CREATIVE TAXATION}

Levying taxes on those things that societies find unsalutary, from alcohol to gambling, is a long-established practice. It makes sense to extend the taxation of 'societal ills' to activities that have made a select few so rich and caused so much of the recent financial havoc.

A financial transaction $\operatorname{tax}(\mathrm{FTT})$ is one such possible funding source. A small FTT collected on the sale of financial assets, such as stock, bonds or futures, would have a negligible effect on trade, but could raise substantial funds: a tax of $0.1 \%$ on equities and $0.02 \%$ on bonds could bring in about $\$ 48$ billion from G20 member states ${ }^{3}$.

A variant of the FTT is a currency-transaction tax, or Tobin tax, named after James Tobin, the economist who proposed it in the 1970s. Foreign-exchange transactions total around $\$ 800$ trillion annually, which means that a Tobin tax of only $0.05 \%$ could raise $\$ 400$ billion a year".

Other taxes hold lucrative promise. A 10\% tax on global arms exports, for example, could raise up to $\$ 5$ billion annually ${ }^{5}$. Additional tobacco-sales taxes in G20 and other European Union (EU) countries could generate an extra $\$ 10.8$ billion; global aviation-fuel taxes $\$ 27$ billion; and shipping-fuel taxes $\$ 37$ billion ${ }^{3}$.

The problem with these taxes is that few nations are likely to want to participate: governments will face intense lobbying pressures and the risk of increased black-market activity. Nevertheless, the EU proposed an FTT at the G20 summit in Cannes, France, in November 2011 as a way to raise development funding for poorer countries. Although favourably received by many G20 countries, the proposal failed to secure full backing because of opposition from the United States, the United Kingdom and Canada, all of which worried about the FTT's added burden to their banks. Europe is still pushing for an FTT.

Despite such obstacles, these methods have the best chance of raising the money needed to make a sustainable planet. It is time that such creative funding mechanisms were discussed more seriously at meetings - such as Rio +20 - at which action is proposed.

Edward Barbier is in the department of economics and finance at the University of Wyoming, Laramie, Wyoming 82071, USA. His latest book is Capitalizing on Nature: Ecosystems as Natural Assets. e-mail:ebarbier@uwyo.edu

1. Ebeling, J. \& Yasué, M. Phil. Trans. R. Soc. B 363, 1917-1924 (2008).

2. The Least Developed Countries Report, 2010 Towards a New International Development Architecture for LDCs (UN Conference on Trade and Development, 2010).

3. Gates, B. Innovation with Impact: Financing 21st-Century Development (Gates Notes, 2011).

4. Spahn, P. B. Broker 22, 10-14 (2010).

5. Brzoska, M. Kyklos 57, 149-172 (2004). 